\title{
Obituary
}

\section{Isabel de Madariaga, FRHistS, FBA 27 August 1919-16 June 2014 Professor of Russian Studies, University of London, Corresponding Member of the Royal Spanish Academy}

It is with great sadness that we have to record the death of a muchloved friend and colleague who did so much to establish the journal, but at the same time it is a pleasure to commemorate her long and fruitful life with a personal memoir.

Isabel de Madariaga was one of the founders, with Ghiţă Ionescu and Leonard Schapiro, of Government and Opposition in 1965. I joined the team as full-time editorial assistant in 1978 to take on the administrative burden which had been largely borne by Isabel (or Lolita or Lol, as she was known to friends and family) with varying degrees of help from support staff.

Dr de Madariaga, or Mrs Schapiro, as she then was, knew how to run a journal from her experience on the Slavonic and East European Review; Ghiţă Ionescu, as well as being a scholar, had once been a journalist in his native Romania, and Leonard Schapiro was a professor at the London School of Economics, which institution helpfully provided an office and some clerical help in the early days. This ideal combination of talent, experience and contacts succeeded in establishing a flourishing, self-supporting enterprise without subsidy from any institution. Lolita's business acumen and willingness to take on practical tasks were crucial and although the original intention had been to include articles on her own subject of history that discipline came to be neglected. Initially she did the copy-editing herself, the skill being enhanced by her outstanding facility for languages: she had learned English from her mother, Spanish from her father, was taught in French at school in Geneva and studied Russian and German at university in England (she was the first 
woman to be admitted to the School of Slavonic and East European Studies, London). Needless to say, she got by in Italian too and when it came to Portuguese would ask the caller if 'Castiliano' would be understood. Lolita recalled one issue where the contributors wrote such approximate English that the whole number had been rewritten by her. Geraint Parry recounted working with her, when he was editor of Government and Opposition, on an article by a German author where she translated the awkward prose back into German then into English for a readable version.

The journal was a side-line for Lolita; she was forging her own career in Russian Studies and published her magnum opus Russia in the Age of Catherine the Great in 1981. Her academic path was not straightforward: she held appointments at Sussex and Lancaster before returning to SSEES as Reader in 1971. She felt that her back problems, which caused so much pain for many years and possibly originated in a fall from a horse in her youth, had been exacerbated by commuting to Lancaster while setting up its department of Russian Studies - which department, sadly, she lived to see closed down by university cuts. She was widely regarded as an inspirational teacher and some of her former pupils achieved eminence in the diplomatic as well as in the academic world. In her youth she was strikingly attractive, and one former student told me that when he attended her tutorials at the LSE with other ex-servicemen in the 1940s, a time when smoking was general, each man would compete to light her cigarette like a Humphrey Bogart or Cary Grant to her Ingrid Bergman. She was feminine rather than a feminist but she did once murmur that women were neglected for promotion at some institutions.

Lolita was notoriously absent-minded, tending not to remember where she had left her belongings, and I would ring her up from the office to say, 'It's OK, your umbrella/fountain pen is here,' as I knew the loss would worry her. One time, on leaving SSEES she put her 'despatch case' on the roof of her car and drove off through Russell Square. An honest bystander found it in the road and returned it to the library of SSEES as it contained reference books bearing the SSEES label: reference books that the poor librarian should not have allowed to leave the building, but Professor de Madariaga was so impressive that she was privileged. On one remarkable occasion Lol left her passport in Switzerland after visiting her stepmother. In her imperious mode she talked her way into the UK - and with a foreign name! Hers was an eminence that would brook no denial. 
After the death of her dear friend Ghiţă Ionescu at her home in Highgate in 1996 there followed a new flowering of her research and writing: she published Ivan the Terrible in 2005 at the age of 86. Work was almost as natural as breathing and the decline of her eyesight was a severe blow as she passed into her nineties.

At her ninetieth birthday dinner Lolita told us that she had had a good life, but I know that it was not without its vicissitudes. Her renowned father Salvador de Madariaga, diplomat and international scholar, being opposed to Franco, had to take the family to England in 1936. Salvador outlived Franco and was able to return to his homeland in triumph in old age, but continued to live in Switzerland (he told Ghiţă Ionescu that he could not go back to eating dinner at 10 p.m. after an absence of so many years).

Lolita and her elder sister Nièves had a happy childhood. Their mother, Constance Archibald, was a woman of fine intellect and an accomplished pianist. Having won a scholarship to do research in Paris after graduating from the University of Glasgow, she met her husband when she was playing the piano there. Lolita's education in Geneva, France and Madrid was followed by school in Oxford where Salvador was given a professorship (the house where they lived recently received a blue plaque at a ceremony attended by Lolita). Her father was always in the background with the admonition to work and achieve, but this did not preclude pleasure and gaiety: Lolita went to the operating theatre for the last time to the accompaniment of a Mozart opera ringing in her ears. She was a woman of great courage who did not let disability prevent her from travelling, despite the annoyance of wheelchairs at airports and waiting for taxis that were often late. She enjoyed entertaining and was a good cook and generous hostess.

Finally I must say that Isabel de Madariaga was the least boring person I have known; time would slip away as we chatted in the office and the paperwork had to wait. She was like a popular teacher who was most interesting when lured 'off the subject'. I was complimented by her wanting to talk for so long to me and feel enriched by having known her. 